\title{
Quantity and Spatial Variability of Soil Carbon in the Conterminous United States
}

\author{
Yinyan Guo, Ronald Amundson,* Peng Gong, and Qian Yu
}

\begin{abstract}
We estimated the soil organic carbon (SOC) and soil inorganic carbon (SIC) inventory for the conterminous USA using the State Soil Geographic Database (STATSGO). The relative contribution of each soil order and Land Resource Region (LRR) to the national SOC and SIC inventory was determined. There are 302 to $1499 \times 10^{8} \mathrm{Mg}$ of SOC and 226 to $937 \times 10^{8} \mathrm{Mg}$ of SIC in the upper $2 \mathrm{~m}$ of soil in the conterminous USA. About 30 and $80 \%$ of the upper $2-\mathrm{m} \mathrm{SOC}$ is in the 0- to 0.20- and 0- to 1.0-m soil layers, respectively. For SIC, only about $8 \%$ of the upper $2-\mathrm{m}$ SIC is in the upper $0.2 \mathrm{~m}$, and about $50 \%$ is in the top $1.0-\mathrm{m}$ layer. The relative spatial variability of SOC increases dramatically as soil depth increases while the largest relative variability of SIC is in the surface layer. Because of its large area ( $27 \%$ of the soil area in the conterminous USA), Mollisols are the largest contributors both to the SOC stock (about 31 to $39 \%$ ) and to the SIC stock (about 43 to $44 \%$ ) in the conterminous USA. The results of this study provide a view of soil $\mathrm{C}$ partitioning by taxonomic group and land resource area, information that may be useful for assessing the impact of land use and climatic change on SOC and SIC pools.
\end{abstract}

$A^{x}$ ACCURATE ASSESSMENT of U.S. soil C storage is needed as a baseline for evaluating the overall U.S. C budget and the impact of land cover/use change on the inventory. Numerous studies have estimated the U.S. SOC pools at local and regional scales (Franzmeier et al., 1985; Sims and Neilsen, 1986; Huntington et al., 1988; Davidson and Lefebvre, 1993; Davidson, 1995; Homann et al., 1998; Brejda et al., 2001; Galbraith et al., 2003). Kern (1994), using data from 3700 pedons, estimated that U.S. soils have between 62.1 and $84.5 \mathrm{Pg}$ $\left(\mathrm{Pg}=10^{15} \mathrm{~g}\right)$ of SOC in the upper $1.0 \mathrm{~m}$. Bliss et al. (1995), using averages (midpoint values) from the STATSGO, estimated SOC storage (total soil profile) in 40 states. Lacelle et al. (2001) later generated a map of SOC in the upper $1.0 \mathrm{~m}$ of the soils of North America, with the U.S. portion calculated using the midpoint values from the STASTGO database.

Soil inorganic $\mathrm{C}$ is also a large $\mathrm{C}$ pool. However, studies on SIC storage and content have only focused on local or regional assessments (Schlesinger, 1982; Grossman et al., 1995; Monger and Matrinez-Rios, 2000). Estimates of the SIC pools at a national or global scale have been more tentative than estimates of SOC pools (Lal et al., 1998b). Nonetheless, most of the SIC, which exists as carbonates, is believed to occur in soils of arid and

Division of Ecosystem Sciences and Center for Assessment and Monitoring of Forest and Environmental Resources (CAMFER), 137 Mulford Hall, College of Natural Resources, Univ. of California, Berkeley, CA 94720-3114. Received 16 May 2005. *Corresponding author (earthy@ nature.berkeley.edu).

Published in Soil Sci. Soc. Am. J. 70:590-600 (2006).

Pedology, Soil \& Water Management \& Conservation

doi:10.2136/sssaj2005.0162

(C) Soil Science Society of America

677 S. Segoe Rd., Madison, WI 53711 USA semiarid regions (Grossman et al., 1995; Schlesinger, 1997; Lal et al., 1998b). Monger and Matrinez-Rios (2000) estimated the amount of soil carbonate in grazing lands of the USA by focusing on the woodlands, shrublands, and grasslands that occur within aridic, ustic, and xeric moisture regimes using random sampling for at least 25 sites per ecoregion. An estimation of SIC storage for the entire USA has not been made.

The STATSGO database is not only amenable for exploring the national distribution of soil properties, but also for examining soil properties within LRR and among the taxa within Soil Taxonomy categories. At this time, no systematic studies of SOC and SIC partitioning by LRRs or soil orders at a national scale have been performed.

The STATSGO database used in this study is a geographic information system (GIS) based relational database compiled by the National Resources Conservation Service (NRCS), which was made by generalizing detailed soil survey data. The level of detail in STATSGO is based on its intended use for planning and management covering state, multi-state, and regional areas. Most importantly, it is the only soil database currently available for evaluating national soil resources (SCS, 1992; Reybold and Gale, 1989). The mapping scale for the STATSGO data is 1:250 000 (with the exception of Alaska) with a minimum mapping unit area of $6.25 \mathrm{~km}^{2}$, equivalent to a square cell of 2.5 by $2.5 \mathrm{~km}$. The basic structure of STATSGO is the map unit and its components. Components are the finest horizontal entities (units) for data recording. A map unit may contain 1 to $21 \mathrm{com}-$ ponents. In the conterminous USA (excluding water, urban land, bare rock, and other non-soil bodies), there are 10441 STATSGO map units (74 590 polygons) and 111247 components (regions within the map units). For each component, its area percentage (\%) within the map unit, its soil classification (Soil Survey Staff, 1999), and its properties for each soil layer ("O" horizon excluded) are reported in a relational database format by experienced local soil scientists based on soil survey results.

The purpose of this study is to calculate total SOC and SIC inventories, as well as the contents (e.g., concentrations, $\left.\mathrm{kg} \mathrm{m}^{-2}\right)$, within three depth intervals $(0-0.2$, $0-1.0$, and $0-2.0 \mathrm{~m}$ ) for the conterminous USA using the STATSGO database, and to examine the partitioning of SOC and SIC pools by natural land resource region and by soil orders in Soil Taxonomy. Our analysis of SOC expands previous STATSGO SOC analyses, and our analyses of SIC for the nation is, to our knowledge, an

Abbreviations: GIS, geographical information system; LRR, land resource region; MRLA, major land resource areas; NRCS, Natural Resources Conservation Service; OM, organic matter; SIC, soil inorganic carbon; SOC, soil organic carbon; STATSGO, state soil geographical database. 
entirely new contribution to the soil carbon inventory literature.

\section{MATERIALS AND METHODS}

\section{Data Sources and Structure}

Soil organic $\mathrm{C}$ is estimated from the organic matter (OM) data recorded in STATSGO as percentage in $<2.0$-mm size fraction. Low (OML) and high (OMH) percentage limits of the $\mathrm{OM}$ for each soil layer of a component are reported. SIC is given as the calcium carbonate equivalent $\left(\mathrm{CaCO}_{3}\right)$ percentage in the $<2.0-\mathrm{mm}$ size fraction $\left(\mathrm{CaCO}_{3}\right.$ in limestone gravel is not included). Low $\left(\mathrm{CaCO}_{3} \mathrm{~L}\right)$ and high $\left(\mathrm{CaCO}_{3} \mathrm{H}\right)$ percentage limits of SIC for each soil layer of a component are recorded in STATSGO. The data in the 48 conterminous USA were used in the study.

\section{Determination of Soil Carbon Storage and Variation}

To calculate the soil C (SOC or SIC) storage, the OM and $\mathrm{CaCO}_{3}$ data (reported on a $<2.0$-mm fraction) was normalized for gravel content. Soil and rock fragment fractions for each soil layer of a component are reported as inch10 $(>250 \mathrm{~mm})$, inch3 (75-250 mm), and 'no10' (<2.0-mm fraction from that which has passed through a $75-\mathrm{mm}$ sieve). The high $(\mathrm{H})$ and low (L) gravel estimates (\%) for each fraction (USDA-NRCS, 2003) are recorded in STATSGO.

The low and high fractions of the soil in the $<2$-mm diameter fraction for a given layer of the soil components within STATSGO were calculated as follows:

$$
\begin{aligned}
Q_{i j k p}(L) & =\left(1-\frac{\operatorname{Inch} 10 H_{i j k p}}{100}-\frac{\operatorname{inch} 3 H_{i j k p}}{100}\right) \times\left(\frac{\text { no10 } L_{i k k p}}{100}\right) \\
Q_{i j k p}(H) & =\left(1-\frac{\text { Inch10 } L_{i j k p}}{100}-\frac{\operatorname{inch} 3 L_{i j k p}}{100}\right) \times\left(\frac{\text { no10 } L_{i j k p}}{100}\right)
\end{aligned}
$$

Where $i$ is the $i^{\text {th }}$ state

$j$ is the $j^{\text {th }}$ map unit in the $i^{\text {th }}$ state

$k$ is the $k^{\text {th }}$ component in the $i j^{\text {th }}$ map unit

$p$ is the $p^{\text {th }}$ layer in the $i j k^{\text {th }}$ component

The midpoint fraction of soil $<2 \mathrm{~mm}$ in diameter for each layer of the component $Q_{i j k p}(M)$ as well as the rock fragment conversion factor $\left(f_{i j k p}\right)$ used to adjust for the volume of rocks in a given layer were calculated in the way used by Bliss et al. (1995).

Soil organic C and SIC storage for each layer of a component was calculated:

$$
\begin{aligned}
\operatorname{SOCT}_{i k k p}(Z)= & (\text { Volume })_{i k k p} \times f_{i j k p}(Z) \times \\
& \left(\frac{\mathrm{OM}_{i k p}(Z)}{100}\right) \times \mathrm{BD}_{i k k p}(Z) \times 0.58 \\
\operatorname{SICT}_{i j k p}(Z)= & (\text { Volume })_{i j k p} \times f_{i j k p}(Z) \times \\
& {\left[\frac{\left(\mathrm{CaCO}_{3}\right)_{i j k p}(Z)}{100}\right] \times \mathrm{BD}_{i j k p}(Z) \times \frac{12}{100} } \\
& (\mathrm{Z}=\text { low limit, midpoint, high limit })
\end{aligned}
$$

where $i, j, k$ and $p$ are defined in Eq. [1]; $\operatorname{SOCT}_{i j k p}(\mathrm{Z})$ is the $\mathrm{SOC}$ (in $\mathrm{Mg}$ ) of the $i j k^{\text {th }}$ layer; (Volume) ${ }_{i j k p}$ is the layer volume $\left(\mathrm{m}^{3}\right)$ calculated by multiplying area $\left(\mathrm{m}^{2}\right)$ with depth $(\mathrm{m})$; $f_{i j k p}(Z)$ is the rock fragment conversion factor; $\mathrm{OM}_{i j k p}(Z)$ is the percent of organic matter; $\mathrm{BD}_{i j k p}(Z)$ is the bulk density; 0.58 is the factor used to convert organic matter to organic $\mathrm{C}$ (Bliss et al., 1995); $\operatorname{SICT}_{i j k p}(Z)$ is the soil inorganic C (in Mg) within the ijkpth layer; $\mathrm{CaCO}_{3 i j k p}(Z)$ is the percentage of
$\mathrm{CaCO}_{3} ; 12 / 100$ is the conversion coefficient used to convert $\mathrm{CaCO}_{3}$ to inorganic $\mathrm{C}$ on a molar basis.

The SOC and SIC storage in the 0- to 0.2-, 0 - to $1-$, and 0 - to 2-m depths of each soil component was calculated by summing the SOC and SIC of the corresponding soil layers, weighted by depth.

The SOC (or SIC) content to $0.2,1$, and $2 \mathrm{~m}$ of each soil component $\left(\mathrm{kg} \mathrm{m}^{-2}\right)$ was calculated as follows:

$$
\begin{aligned}
& \operatorname{SCD}_{i j k}(Z D)=\frac{\operatorname{SCT}_{i j k}(Z D)}{(\text { Area })_{i j k}} \times 1000 \\
& (\mathrm{Z}=\text { low limit, midpoint, high limit }) \\
& (\mathrm{D}=0-0.02 \mathrm{~m}, 0-1.0 \mathrm{~m}, 0-2.0 \mathrm{~m})
\end{aligned}
$$

where $i, j$, and $k$ are defined in Eq.[1]; $\operatorname{SCD}_{i j k}(Z D)$ is SOC (or SIC) content $\left(\mathrm{kg} \mathrm{m}^{-2}\right)$ of the $i j k^{\text {th }}$ component for depth $(D)$ and method $(Z) ; \mathrm{SCT}_{i j k}(Z D)$ is total SOC (or SIC) storage (in $\mathrm{Mg}$ ) of the $i j k^{\text {th }}$ component for depth $(D)$ and method $(Z)$. $(\text { Area })_{\mathrm{ijk}}$ is the $i j k^{\text {th }}$ soil component area $\left(\mathrm{m}^{2}\right)$.

Total SOC (or SIC) storage $\operatorname{SCT}_{i j}(Z D)$ and content $\mathrm{SCD}_{i j}(Z D)$ in each map unit were estimated as follows:

$$
\begin{aligned}
& \operatorname{SCT}_{i j}(Z D)=\sum_{k}^{p} \operatorname{SCT}_{i j k}(Z D) \\
& \operatorname{SCD}_{i j}(Z D)=\sum_{k}^{p} \frac{(\text { Area })_{i j k}}{\sum_{k}^{p}(\text { Area })_{i j k}} \times \operatorname{SCD}_{i j k}(Z D) \\
& (Z=\text { low limit, midpoint, high limit }) \\
& (D=0-0.02 \mathrm{~m}, 0-1 \mathrm{~m}, 0-2 \mathrm{~m})
\end{aligned}
$$

where $p$ is the number of the soil components (non-soils excluded) in the $i j$ th the map unit; $\operatorname{SCT}_{i j k}(\mathrm{ZD})$, (Area) $)_{i j k \text {, and }}$ $\operatorname{SCD}_{i j k}(Z D)$ are defined in Eq. [3].

Soil organic $\mathrm{C}$ (or SIC) storage $\operatorname{SCT}_{i}(Z D)$ and content $\operatorname{SCD}_{i}(Z D)$ in the $i$ th state were estimated as follows:

$$
\begin{aligned}
& \operatorname{SCT}_{i}(Z D)=\sum_{j}^{t} \operatorname{SCT}_{i j}(Z D) \\
& \operatorname{SCD}_{i}(Z D)=\sum_{j}^{t} \frac{(\text { Area })_{i j}}{\sum_{l}^{t}(\text { Area })_{i j}} \times \operatorname{SCD}_{i j}(Z D) \\
& (\mathrm{Z}=\text { low limit, midpoint, high limit }) \\
& (\mathrm{D}=0-0.02 \mathrm{~m}, 0-1 \mathrm{~m}, 0-2 \mathrm{~m})
\end{aligned}
$$

where $t$ is the number of the map units (non-soil bodies excluded) within the $i^{\text {th }}$ state. $\operatorname{SCT}_{i j}(Z D)$ and $\operatorname{SCD}_{i j}(Z D)$ are defined in Eq. [4]. (Area) $)_{i j}$ is soil area of the $i j^{\text {th }}$ map units.

Soil organic C (or SIC) storage $\operatorname{SCT}(Z D)$ and content $\operatorname{SCD}(Z D)$ for the conterminous USA were calculated in a way similar to Eq. [5].

The variance $\operatorname{SCS}^{2}(D)_{i}$, and the coefficient of variation $\mathrm{CV}(D)$, of SOC (or SIC) among soil components in the $i^{\text {th }}$ state using the midpoint approach was calculated as follows (Gnedenko and Khinchin, 1962):

$$
\begin{aligned}
\operatorname{SCS}^{2}(D)_{i}= & \sum_{j}^{t} \sum_{k}^{p} \frac{(\text { Area })_{i j k}}{\sum_{j}^{t} \sum_{k}^{p}(\text { Area })_{i j k}} \times\left[\operatorname{SCD}(D)_{i j k}\right]^{2}- \\
& {\left[\sum_{j}^{t} \sum_{k}^{p} \frac{(\text { Area })_{i j k}}{\sum_{j}^{t} \sum_{k}^{p}(\text { Area })_{i j k}} \times \operatorname{SCD}(D)_{i j k}\right]^{2} } \\
\operatorname{CV}(D)_{i}= & \frac{\sqrt{\operatorname{SCS}(D)_{i}}}{\operatorname{SCD}(D)_{i}} \times 100 \\
& (D=0-0.02 \mathrm{~m}, 0-1 \mathrm{~m}, 0-2 \mathrm{~m})
\end{aligned}
$$


where $\operatorname{SCD}(D)_{i}$ is SOC (or SIC) content in the $i^{\text {th }}$ state; Area ${ }_{i j k}$, and $\operatorname{SCD}_{i j k}(D)$ are the same as those defined in Eq. [3].

The area weighted variance $\mathrm{SCS}^{2}(\mathrm{D})$, and the coefficient of variation $\mathrm{CV}(D)$, of SOC (or SIC) among soil components in the conterminous USA determined by the midpoint approach were calculated in a way similar to Eq. [6].

\section{Determination of Total Soil Carbon within a Land Resource Region}

Land resource regions are geographically associated land resource units defined by USDA-NRCS (USDA-SCS, 1981). Land resource regions are designated by capital letters and identified by a descriptive name. Land resource regions, A through $\mathrm{U}$, with the exception of $\mathrm{Q}$, are found in the conterminous 48 states. Each LRR is further divided into Major Land Resources Areas (MLRAs). We calculated the SOC (or SIC) for each MLRA. Then, the SOC (or SIC) in each LRR was calculated from the MLRAs within the LRR. The area weighted variance and coefficient of variation for SOC (or SIC) of the soil components within each LRR, and within LRRs, using the midpoint approach were determined in the way similar to the Eq. [6].

\section{Determination of Soil Carbon Storage within Each Soil Order}

The six taxonomic categories (in order of increasing detail: order, suborder, great group, subgroup, family, and series) of each soil component are given in STATSGO. We calculated the SOC and SIC storage and content for each soil order. The variance and coefficient of variation of SOC (or SIC) among soil components in each taxon of the Soil Taxonomy were estimated in the way similar to Eq. [6].

\section{Treatment of Missing Data}

Each empty record (blank or zero value) of 12 fields (OML, OMH, BDL, BDH, no10L, no10H, inch3L, inch3H, inch10L, inch $10 \mathrm{H}, \mathrm{CaCO}_{3} \mathrm{~L}$, and $\mathrm{CaCO}_{3} \mathrm{H}$ ) was checked to determine the completeness of the dataset.

The following assumptions were used to determine if an empty record in OML and OMH fields is a missing datum: (1) OML and OMH should be zero for the following textures: WB (weathered bedrock), UWB (unweathered bedrock), CEM (cemented), and IND (indurated); (2) a zero value is acceptable for OMH if the texture is ICE (ice or frozen soil), FRAG (fragmental material), G (gravel), and CIND (cinders); (3) a zero value for OML is acceptable in mineral or inorganic, but not for organic or organic-modified textures. All other empty records were considered to be missing data if found in OML and $\mathrm{OMH}$ fields. If a missing datum occurs in the middle layer of a soil profile, the average OM (OML or OMH) values of its next (upper and lower) layers were used to fill in the missing data. For the remaining missing records determined in the $\mathrm{OMH}$ and OML fields, the method of Amichev and Galbraith (2004) was used to estimate values for the missing data.

An empty bulk density record in the BDL and BDH fields is considered to be missing data if the other soil properties such as OM (OML, OMH), no10 (no10L, no10H), etc. in the same layer have non-zero values. The missing bulk density values were first estimated according to Brejda et al. (2001). The method of Amichev and Galbraith (2004) was then used to estimate values for missing data that were unable to be determined by the method of Brejda et al.

An empty soil fraction record $(<2 \mathrm{~mm}$ in size $)$ in no10L and no10H fields is considered as a missing data point if the records of the other soil properties such as OM (OML, OMH) and bulk density (BDL, BDH) in the same layer have a nonzero value. If a missing data point occurs in the middle layer of a soil profile, the average no10 value (no10L or no10H) of the adjacent (upper and lower) layers was used to fill in the missing data. For the remainder of the missing data in the no10L and no10H fields, the method of Amichev and Galbraith (2004) was used to calculate the missing data.

An empty rock fragment fraction record $(>250 \mathrm{~mm}$ is size $)$ in the inch10L and inch10H fields is considered to be missing data if the TEXTUREs-left (rock fragment modifier) code is ST (stony), STV (very stony), STX (extremely stony), BY (bouldery), BYV (very bouldery), and BYX (extremely bouldery), indicating that the layer should contain $\geq 15 \%$ volume of stones. Missing data was assumed if there is an empty record in the smaller sized rock fragment fraction $(75-250 \mathrm{~mm}$ in size) of the inch $3 \mathrm{~L}$ and inch $3 \mathrm{H}$ fields when the TEXTUREsleft code is CB (cobbly), CBA (angular cobbly), CBV (very cobbly), CBX (extremely cobbly), CN (channery), CNV (very channery), CNX (extremely channery), FL (flaggy), FLV (very flaggy), and FLX (extremely flaggy). It was also assumed that a soil layer with stones should also contain smaller size rock fragments. The missing data of the rock fragment fraction (inch10L, inch10H, inch3L, and inch3H) were estimated according to Amichev and Galbraith (2004).

If all data layers of a component are empty in $\mathrm{CaCO}_{3} \mathrm{~L}$ and $\mathrm{CaCO}_{3} \mathrm{H}$ fields when the soil has the formative element "Calc" at great group or subgroup taxonomy levels, or has the "carbonatic" element at family level of Soil Taxonomy, the component is considered to have at least one missing datum in the $\mathrm{CaCO}_{3} \mathrm{~L}$ and $\mathrm{CaCO} 3 \mathrm{H}$ fields. This missing component was then estimated using the average $\mathrm{CaCO}_{3} \mathrm{~L}$ ( or $\mathrm{CaCO}_{3} \mathrm{H}$ ) values of the same layer in other soil components that have the same taxon (filling in priority: the series, family, subgroup, and great group in Soil Taxonomy) within the same map unit, or within in nearby map units of the same MLRA, and or the map units of the same land resource region.

The 368942 layers of data for 111247 components (excluding water, urban land, bare rock, and other non-soil bodies) in STATSGO were checked, and the missing values were filled in based on the assumptions and the filling methods described above.

The original projection of STATSGO was retained except the datum was changed from NAD27 to NAD83 using ARC/INFO software (Environmental Systems Research Institute, 1998). All calculations were processed using programs written by the senior author using the visual basic language in Microsoft Access (Microsoft Corporation, 2000) and Avenue language in ArcView (Environmental Systems Research Institute, 1999).

\section{RESULTS AND DISCUSSION Soil Carbon by State, Resource Region, and the USA}

The results of the SOC and SIC calculations for the three depth intervals are presented in Table 1. For the total reported (in STATSGO) soil area in the conterminous USA $\left(737 \times 10^{4} \mathrm{~km}^{2}\right)$, the SOC and SIC sequestered in the upper 2-m ranges between 302 and $1499 \times$ $10^{8} \mathrm{Mg}$ and 226 to $937 \times 10^{8} \mathrm{Mg}$, respectively. About $30 \%$ of the SOC in the upper $2 \mathrm{~m}$ is stored in the 0 - to $0.2-\mathrm{m}$ surface layer and about $80 \%$ is in the upper $1.0 \mathrm{~m}$. For SIC, only about $8 \%$ was found in the surface layer, and about $50 \%$ was in the top $1.0 \mathrm{~m}$. Soil inorganic $\mathrm{C}$ is less than SOC based on the data in STATSGO. 
Table 1. Soil C storage and content in the conterminous USA by soil depth.

\begin{tabular}{|c|c|c|c|c|c|c|c|c|c|c|c|c|c|c|c|}
\hline \multirow[b]{3}{*}{ Depth } & \multicolumn{7}{|c|}{ Organic C } & \multicolumn{7}{|c|}{ Inorganic C } & \multirow[b]{3}{*}{$r \#$} \\
\hline & \multicolumn{3}{|c|}{ Total storage, $10^{8} \mathrm{Mg}$} & \multicolumn{4}{|c|}{ Content, $\mathrm{kg} \mathrm{m}^{-2}$} & \multicolumn{3}{|c|}{ Total storage, $\mathbf{1 0}^{8} \mathrm{Mg}$} & \multicolumn{4}{|c|}{ Content, $\mathrm{kg} \mathrm{m}^{-2}$} & \\
\hline & $\operatorname{Min} \dagger$ & Mid $\$$ & Max§ & Min & Mid & Max & CVII & Min & Mid & Max & Min & Mid & $\operatorname{Max}$ & CV & \\
\hline $\mathbf{c m}$ & & & & & & & & & & & & & & & \\
\hline 0-20 & 116 & 238 & 392 & 1.57 & 3.23 & 5.31 & 115 & 18 & 41 & 71 & 0.25 & 0.56 & 0.96 & 333 & 0.0033 \\
\hline 20-100 & 138 & 401 & 740 & 1.87 & 5.44 & 10.03 & 209 & 102 & 240 & 414 & 1.38 & 3.26 & 5.61 & 261 & 0.0004 \\
\hline 100-200 & 48 & 187 & 368 & 0.65 & 2.54 & 4.99 & 321 & 106 & 260 & 453 & 1.43 & 3.53 & 6.15 & 279 & 0.0006 \\
\hline $0-200$ & 302 & 826 & 1499 & 4.09 & 11.20 & 20.33 & 190 & 226 & 541 & 937 & 3.07 & 7.34 & 12.71 & 248 & 0.0004 \\
\hline
\end{tabular}

$\dagger$ Minimum.

$\$$ Midpoint.

$\S$ Maximum.

II Coefficient of variation (\%) among soil components with midpoint approach.

\# Coefficient of correlation in soil components with midpoint approach.

However, it should be mentioned that SIC in this study refers only to SIC in $<2$-mm size fraction, and the $\mathrm{CaCO}_{3}$ within limestone gravel is not included.

The coefficient of variation of SOC (or SIC) illustrates the relative spatial variability of SOC (or SIC) among the soil components. The relative spatial variability of SOC increases dramatically as soil depth increases, while the largest relative spatial variability of SIC is in the surface layer. No obvious linear correlation relationship between SOC and SIC, at any soil depth, was found.

Use of multiple data sources or methods to estimate the U.S. SOC pool should improve the confidence in these estimates, though STATSGO is the only national soil database presently available. In previous work, Bliss et al. (1995) used midpoint values from STATSGO to determine the SOC storage (total in the soil profile) in 40 states. Lacelle et al. (2001) generated a map of SOC in the upper $1 \mathrm{~m}$ of North America (the U.S. portion was again based on STATSGO midpoint values). While the midpoint value may yield reasonable stock estimates, low and high limits provide conservative bounds to the U.S. soil C stocks.

Most estimates of SOC in the USA are limited to the upper $1 \mathrm{~m}$. Here, we calculated that the SOC in the upper $1.0 \mathrm{~m}$ of the conterminous USA ranges from 254 to $1131 \times 10^{8} \mathrm{Mg}$, with a midpoint value of $639 \times 10^{8} \mathrm{Mg}$. Using laboratory data from 3700 pedons, Kern (1994) estimated that the SOC in the upper $1 \mathrm{~m}$ in the USA is between 621 and $845 \times 10^{8} \mathrm{Mg}$, a range obtained by scaling up the pedon data using three approaches: ecosystem, great-group taxonomic unit, and soil map of world-based methods. In general, Kern's result is similar to our estimated midpoint value suggesting that the STATSGO data and approach are reliable for $\mathrm{C}$ inventory analyses.

The spatial distribution of SOC and SIC in the upper $2.0 \mathrm{~m}$ is presented in Fig. 1 and Fig. 2. The spatial SOC distribution is similar in most details to the map generated by Kern (1994) to $1.0 \mathrm{~m}$ and to the SOC map of North America by Lacelle et al. (2001). The eastern Great Plains and Midwest have the highest SOC content, though some high SOC regions in the East Coast, Gulf Coast, and Pacific Northwest also occur. For SIC, the highest SIC storage is in Texas, though the Midwest also has a high SIC storage in the Upper $2.0 \mathrm{~m}$. There are some obvious SIC changes across state boundaries - for example between Iowa and South Dakota. This indicates that some SIC data might be still missing in these states or the soil survey results should be correlated between states since current results were based on surveys conducted separately in each state.

Considering the soil $\mathrm{C}$ by USDA-NRCS regions, about 23 to $32 \%$ of the U.S. SOC is in the Midwest, 17 to $20 \%$ in the Southeast, 18 to $19 \%$ in the Northern Plains, 15 to $16 \%$ in the West, and 13 to $15 \%$ in the South Central regions (Table 2). When $\mathrm{C}$ in each state is compared, Texas has the largest SOC (to $2.0 \mathrm{~m}$ ) with 2544 to $12509 \times 10^{6} \mathrm{Mg}$, accounting for $8 \%$ of the total SOC in the conterminous USA. This value is followed by Minnesota ( 2315 to $9523 \times 10^{6} \mathrm{Mg}, 6$ to $8 \%$ ), Florida (1686 to $8734 \times 10^{6} \mathrm{Mg}, 6 \%$ ), Michigan and Iowa (about $4 \%$ using midpoint values, respectively). In terms of the SOC content (top $2.0 \mathrm{~m}$ by the midpoint value), Florida has the highest average content $\left(35.3 \mathrm{~kg} \mathrm{~m}^{-2}\right)$, followed by Minnesota $\left(25.9 \mathrm{~kg} \mathrm{~m}^{-2}\right)$, Michigan $\left(24.1 \mathrm{~kg} \mathrm{~m}^{-2}\right)$, Wisconsin $\left(20.6 \mathrm{~kg} \mathrm{~m}^{-2}\right)$, and Iowa $\left(20.5 \mathrm{~kg} \mathrm{~m}^{-2}\right)$.

The spatial pattern of SIC in the upper $2.0 \mathrm{~m}$ is different from that of SOC. About 37 to $40 \%$ of total SIC is in the South Central region, 23 to $26 \%$ in the West, $19 \%$ in the Northern Plains, and 14 to $20 \%$ in the Midwest regions. The East and Southeast regions have little SIC. State wise, Texas has the largest SIC with 867832 to $3240934 \times 10^{4} \mathrm{Mg}$ (about 35 to $38 \%$ ), followed by New Mexico (about 7\%, midpoint method), Montana (6\%), Utah (6\%), and Minnesota (5\%). Analysis of the SIC content (to $2.0 \mathrm{~m}$ ) using the midpoint approach showed that Texas has the highest SIC at $29.0 \mathrm{~kg} \mathrm{~m}^{-2}$, followed by Utah $\left(18.0 \mathrm{~kg} \mathrm{~m}^{-2}\right)$, Minnesota $\left(14.1 \mathrm{~kg} \mathrm{~m}^{-2}\right)$, New Mexico $\left(13.1 \mathrm{~kg} \mathrm{~m}^{-2}\right)$, and Michigan $\left(12.2 \mathrm{~kg} \mathrm{~m}^{-2}\right)$.

It is widely recognized that SIC occurs in soils of arid and semiarid regions (Grossman et al., 1995; Schlesinger, 1997; Lal et al., 1998b; Monger and MatrinezRios, 2000), a pattern also observed here for the upper $1.0 \mathrm{~m}$. However, when SIC to $2.0 \mathrm{~m}$ in soil depth is considered, our results show that there is a large SIC pool in the Midwest, where mean annual precipitation (MAP) is about 700 to $1000 \mathrm{~mm}$. While the SIC in the upper $1.0 \mathrm{~m}$ is generally leached out in these climates (Jenny and Leonard, 1934), the deeper depth increments still retain a mixture of both primary and secondary carbonates. In the Midwest, the SIC to $2.0 \mathrm{~m}$ strongly correlates spatially with the extent of the last 


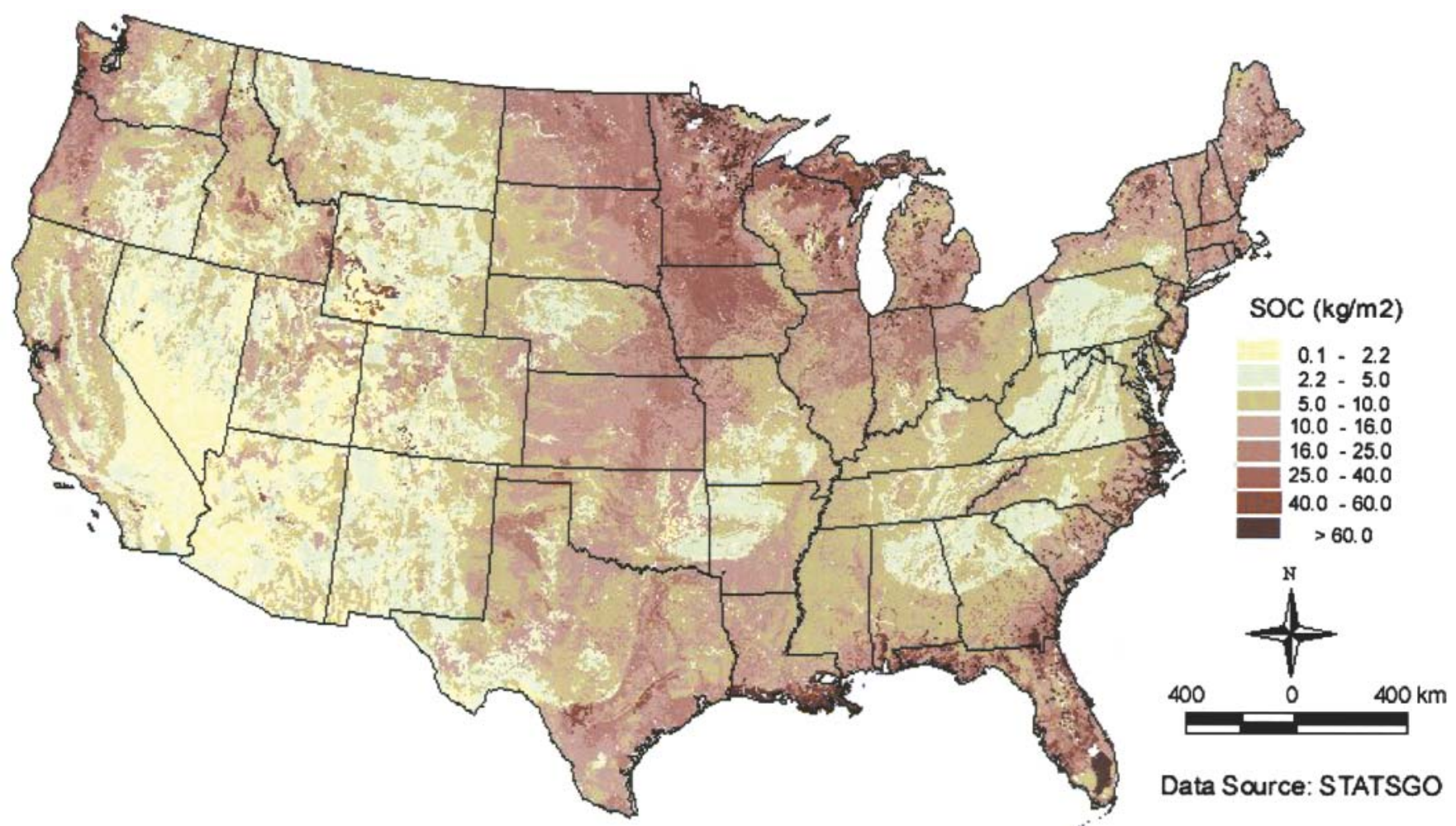

Fig. 1. Spatial distribution of soil organic C (SOC) content to 2-m soil depths in the conterminous USA (midpoint method).

glaciation (Schruben et al., 1998), suggesting these recently rejuvenated areas retain carbonate derived from calcareous sediments of various types. The SIC pattern in the south central plains (particularly Texas) matches the pattern of bedrock (Schruben et al., 1998). There is little SIC in the East and Southeast to 2.0-m depths because of the high mean annual precipitation (MAP). In contrast, there is high SIC in the West due to the arid

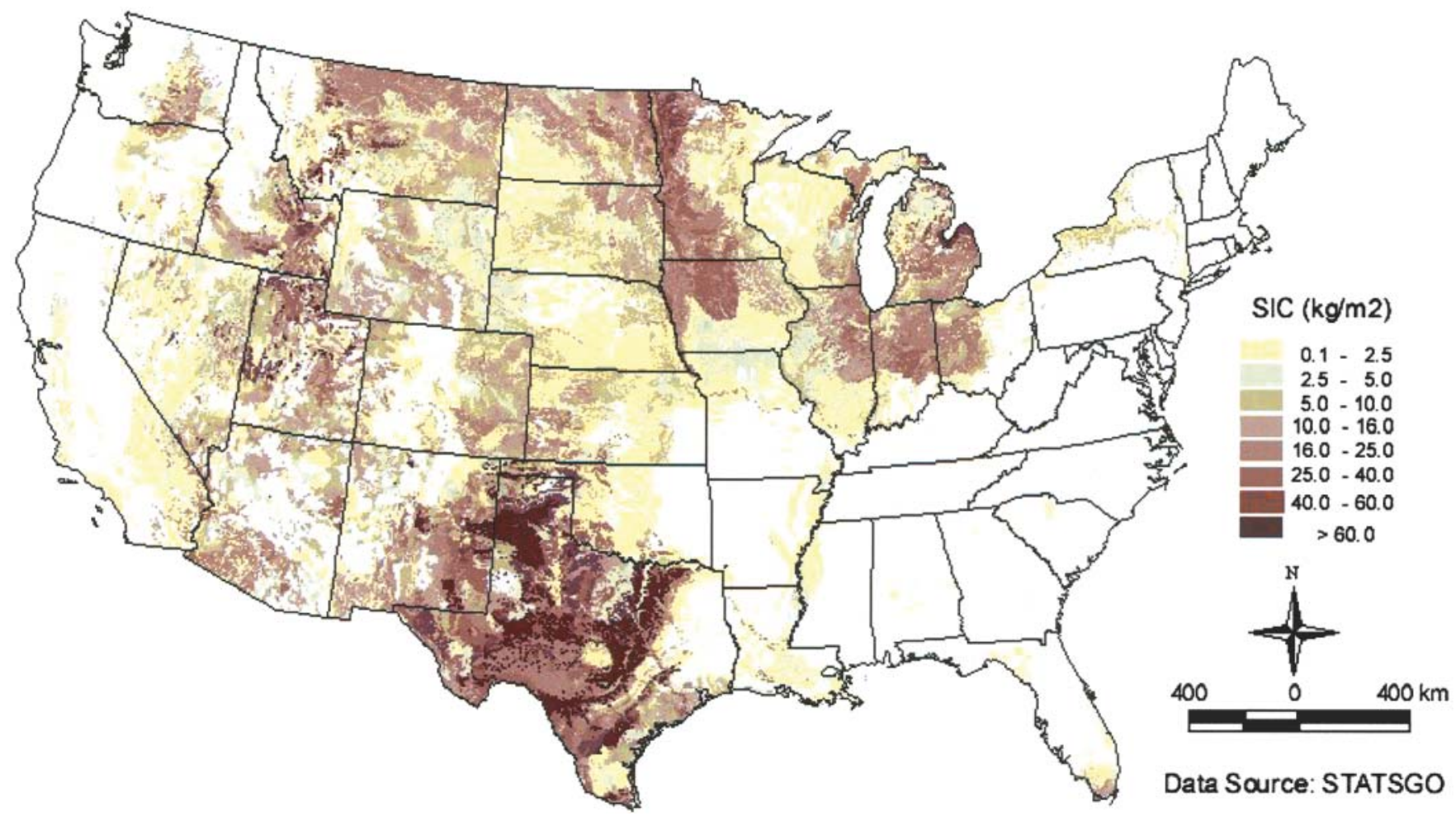

Fig. 2. Spatial distribution of soil inorganic C (SIC) content, to 2-m soil depths, in the conterminous USA (midpoint method). 
and semiarid climate and to the bedrock and aerosol sources of carbonate (Monger and Matrinez-Rios, 2000).

\section{Quantity and Spatial Variability of Soil Carbon in the Land Resource Regions}

The $\mathrm{C}$ storage and content in each LRR are presented in Table 3. About 12 to $20 \%$ of total U.S. SOC is in LRR M (Central Feed Grains and Livestock Region) and 9 to $10 \%$ is in both the LRR T (Atlantic and
Gulf Coast Lowland Forest and Crop Region) and the LRR K (Northern Lake States Forest and Forage Region) regions. The highest SOC content $(2.0 \mathrm{~m}$, midpoint method) is LRR U (Florida Subtropical Fruit, Truck Crop, and Range Region) with $39.6 \mathrm{~kg} \mathrm{~m}^{-2}$. Other regions with remarkable SOC contents are: LRR T (Atlantic and Gulf Coast Lowland Forest and Crop Region) with $35.3 \mathrm{~kg} \mathrm{~m}^{-2}$, LRR K (Northern Lake States Forest and Forage Region) with $25.2 \mathrm{~kg} \mathrm{~m}^{-2}$, and LRR L (Lake States Fruit, Truck, and Dairy Region) with $20.9 \mathrm{~kg}$

Table 2. Soil C storage and content in the upper 2-m depth soil of each state (region).

\begin{tabular}{|c|c|c|c|c|c|c|c|c|c|c|c|c|c|c|c|}
\hline \multirow[b]{3}{*}{ States (Regions) } & \multirow[b]{3}{*}{ Area $\dagger$} & \multicolumn{7}{|c|}{ Organic C } & \multicolumn{7}{|c|}{ Inorganic $\mathbf{C}$} \\
\hline & & \multicolumn{3}{|c|}{ Total storage, $1^{6} \mathrm{Mg}$} & \multicolumn{4}{|c|}{ Content, $\mathrm{kg} \mathrm{m}^{-2}$} & \multicolumn{3}{|c|}{ Total storage, $\mathbf{1 0}^{4} \mathrm{Mg}$} & \multicolumn{4}{|c|}{ Content, $\mathrm{kg} \mathrm{m}^{-2}$} \\
\hline & & Min & Mid§ & Max II & Min & Mid & Max & CV\# & Min & Mid & Max & Min & Mid & Max & CV \\
\hline & $\mathbf{k m}^{2}$ & & & & & & & & & & & & & & \\
\hline Connecticut & 12406 & $\mathbf{5 0}$ & 195 & 423 & 4.1 & 15.7 & 34.1 & 196 & 14 & 84 & 200 & 0.0 & 0.1 & 0.2 & 2204 \\
\hline Delaware & 5043 & 28 & 134 & 290 & 5.6 & 26.6 & 57.5 & 190 & $\mathbf{0}$ & $\mathbf{0}$ & $\mathbf{0}$ & 0.0 & 0.0 & 0.0 & \\
\hline Massachusetts & 18918 & 75 & 324 & 696 & 4.0 & 17.1 & 36.8 & 173 & 1 & 53 & 130 & 0.0 & 0.0 & 0.1 & 1822 \\
\hline Maryland & 25266 & 83 & 338 & 724 & 3.3 & 13.4 & 28.7 & 271 & 0 & $\mathbf{0}$ & 0 & 0.0 & 0.0 & 0.0 & \\
\hline Maine & 80584 & 422 & 1331 & 2676 & 5.2 & 16.5 & 33.2 & 160 & 20 & 77 & 156 & 0.0 & 0.0 & 0.0 & 4970 \\
\hline New Hampshire & 22801 & 68 & 357 & 807 & 3.0 & 15.6 & 35.4 & 122 & 0 & 8 & 19 & 0.0 & 0.0 & 0.0 & 4012 \\
\hline New Jersey & 17788 & 105 & 295 & 588 & 5.9 & 16.6 & 33.0 & 171 & 1 & 47 & 112 & 0.0 & 0.0 & 0.1 & 1587 \\
\hline New York & 118432 & 480 & 1595 & 3236 & 4.1 & 13.5 & 27.3 & 135 & 2321 & 15149 & 34835 & 0.2 & 1.3 & 2.9 & 320 \\
\hline Pennsylvania & 115291 & 168 & 683 & 1481 & 1.5 & 5.9 & 12.8 & 95 & 0 & 321 & 892 & 0.0 & 0.0 & 0.1 & 2027 \\
\hline Rhode Island & 2583 & 13 & 45 & 96 & 5.1 & 17.5 & 37.1 & 174 & 0 & 2 & 5 & 0.0 & 0.0 & 0.0 & 834 \\
\hline Vermont & 23764 & 65 & 344 & 775 & 2.7 & 14.5 & 32.6 & 90 & 263 & 1312 & 2951 & 0.1 & 0.6 & 1.2 & 796 \\
\hline West Virginia & 61448 & 65 & 296 & 640 & 1.1 & 4.8 & 10.4 & 43 & 53 & 253 & 472 & 0.0 & 0.0 & 0.1 & 2835 \\
\hline (East) & 504325 & 1622 & 5937 & 12431 & 3.2 & 11.8 & 24.6 & 175 & 2674 & 17306 & 39773 & 0.1 & 0.3 & 0.8 & 682 \\
\hline Iowa & 143801 & 1915 & 2944 & 4087 & 13.3 & 20.5 & 28.4 & 74 & 40155 & 167537 & 314423 & 2.8 & 11.7 & 21.9 & 118 \\
\hline Illinois & 143948 & 914 & 1828 & 2889 & 6.3 & 12.7 & 20.1 & 84 & 14878 & 107565 & 222676 & 1.0 & 7.5 & 15.5 & 138 \\
\hline Indiana & 93584 & 534 & 1309 & 2273 & 5.7 & 14.0 & 24.3 & 189 & 35224 & 110397 & 205506 & 3.8 & 11.8 & 22.0 & 123 \\
\hline Michigan & 147532 & 1655 & 3561 & 5978 & 11.2 & 24.1 & 40.5 & 182 & 74503 & 179879 & 318875 & 5.0 & 12.2 & 21.6 & 130 \\
\hline Minnesota & 209223 & 2315 & 5416 & 9523 & 11.1 & 25.9 & 45.5 & 119 & 110233 & 295235 & 523666 & 5.3 & 14.1 & 25.0 & 125 \\
\hline Missouri & 177484 & 665 & 1557 & 2698 & 3.7 & 8.8 & 15.2 & 82 & 2647 & 21428 & 43194 & 0.1 & 1.2 & 2.4 & 404 \\
\hline Ohio & 105442 & 339 & 1071 & 2025 & 3.2 & 10.2 & 19.2 & 121 & 21220 & 66209 & 124664 & 2.0 & 6.3 & 11.8 & 192 \\
\hline Wisconsin & 140542 & 1251 & 2889 & 5077 & 8.9 & 20.6 & 36.1 & 184 & 11383 & 55132 & 116698 & 0.8 & 3.9 & 8.3 & 229 \\
\hline (Midwest) & 1161556 & 9587 & 20574 & 34550 & 8.3 & 17.7 & 29.7 & 155 & 310243 & 1003383 & 1869702 & 2.7 & 8.6 & 16.1 & 159 \\
\hline Arkansas & 135832 & 337 & 1075 & 2031 & 2.5 & 7.9 & 15.0 & 60 & 566 & 4653 & 9739 & 0.0 & 0.3 & 0.7 & 646 \\
\hline Louisiana & 109273 & 446 & 2180 & 4765 & 4.1 & 20.0 & 43.6 & 155 & 4084 & 17525 & 34661 & 0.4 & 1.6 & 3.2 & 502 \\
\hline Oklahoma & 176647 & 579 & 1675 & 3006 & 3.3 & 9.5 & 17.0 & 70 & 41115 & 93171 & 156070 & 2.3 & 5.3 & 8.8 & 331 \\
\hline Texas & 660649 & 2544 & 7002 & 12509 & 3.9 & 10.6 & 18.9 & 82 & 867832 & 1918841 & 3240934 & 13.1 & 29.0 & 49.1 & 133 \\
\hline (South Central) & 1082402 & 3905 & 11932 & 22312 & 3.6 & 11.0 & 20.6 & 115 & 913597 & 2034190 & 3441404 & 8.4 & 18.8 & 31.8 & 179 \\
\hline Alabama & 130948 & 336 & 1207 & 2312 & 2.6 & 9.2 & 17.7 & 265 & 199 & 350 & 525 & 0.0 & 0.0 & 0.0 & 2481 \\
\hline Florida & 136490 & 1686 & 4816 & 8734 & 12.4 & 35.3 & 64.0 & 180 & 4815 & 8572 & 13161 & 0.4 & 0.6 & 1.0 & 758 \\
\hline Georgia & 149285 & 658 & 2015 & 3684 & 4.4 & 13.5 & 24.7 & 249 & 379 & 1119 & 2002 & 0.0 & 0.1 & 0.1 & 1081 \\
\hline Kentucky & 101847 & 194 & 742 & 1482 & 1.9 & 7.3 & 14.6 & 56 & 341 & 1466 & 2726 & 0.0 & 0.1 & 0.3 & 1273 \\
\hline Mississippi & 122583 & 279 & 1279 & 2475 & 2.3 & 10.4 & 20.2 & 256 & 0 & 3411 & 7708 & 0.0 & 0.3 & 0.6 & 427 \\
\hline North Carolina & 125522 & 1044 & 2789 & 5046 & 8.3 & 22.2 & 40.2 & 245 & 0 & 67 & 148 & 0.0 & 0.0 & 0.0 & 2840 \\
\hline South Carolina & 78489 & 413 & 1410 & 2638 & 5.3 & $\mathbf{1 8 . 0}$ & 33.6 & 237 & 513 & 1483 & 2642 & 0.1 & 0.2 & 0.3 & 680 \\
\hline Tennessee & 104277 & 168 & 738 & 1484 & 1.6 & 7.1 & 14.2 & 61 & 3 & 319 & 715 & 0.0 & 0.0 & 0.1 & 1306 \\
\hline Virgi & 102714 & 216 & 824 & 1625 & 2.1 & 8.0 & 15.8 & 301 & o & 212 & 468 & 0.0 & 0.0 & 0.0 & 1441 \\
\hline & 1052154 & 4993 & 15819 & 29479 & 4.7 & 15.0 & 28. & 25 & 6249 & 16998 & 30095 & 0.1 & 0.2 & 0.3 & 1202 \\
\hline Colorado & 253888 & 631 & 1739 & 31 & 2.5 & 6.8 & 12.4 & 161 & 50653 & 144537 & 256260 & 2.0 & 5.7 & 10.1 & 191 \\
\hline Kansas & 212325 & 1120 & 2776 & 46 & 5.3 & 13.1 & 21.9 & 51 & 54371 & 100554 & 153816 & 2.6 & 4.7 & 7.2 & 230 \\
\hline Montana & 350837 & 874 & 2287 & 4168 & 2.5 & 6.5 & 11.9 & 99 & 162908 & 340038 & 574851 & 4.6 & 9.7 & 16.4 & 156 \\
\hline North Dakota & 178589 & 924 & 2869 & 5316 & 5.2 & 16.1 & 29.8 & 53 & 67613 & 181420 & 325895 & 3.8 & 10.2 & 18.2 & 156 \\
\hline Nebraska & 198419 & 796 & 1985 & 331 & 4.0 & 10.0 & 16. & 68 & 9010 & 49848 & 96853 & 0.5 & 2.5 & 4.9 & 235 \\
\hline South Dakota & 191914 & 823 & 2295 & 404 & 4.3 & 12.0 & 21.1 & 64 & 40247 & 106339 & 185273 & 2.1 & 5.5 & 9.7 & 201 \\
\hline Wyoming & 229275 & 389 & 1340 & 2511 & 1.7 & 5.8 & 11.0 & 259 & 55411 & 132376 & 226474 & 2.4 & 5.8 & 9.9 & 175 \\
\hline (Northern Plains) & 1615247 & 5556 & 15292 & 27147 & 3.4 & 9.5 & 16.8 & 105 & 440213 & 1055112 & 1819422 & 2.7 & 6.5 & 11.3 & 188 \\
\hline Arizona & 266867 & 218 & 1001 & 1979 & 0.8 & 3.8 & 7.4 & 90 & 67154 & 195767 & 357557 & 2.5 & 7.3 & 13.4 & 165 \\
\hline California & 353973 & 892 & 2680 & 4843 & 2.5 & 7.6 & 13.7 & 252 & 15451 & 40133 & 75087 & 0.4 & 1.1 & 2.1 & 542 \\
\hline Idaho & 197155 & 660 & 1836 & 3430 & 3.3 & 9.3 & 17.4 & 128 & 70248 & 159972 & 281553 & 3.6 & 8.1 & 14.3 & 193 \\
\hline New Mexico & 284358 & 338 & 1491 & 2898 & 1.2 & 5.2 & 10.2 & 93 & 177792 & 371331 & 612609 & 6.3 & 13.1 & 21.5 & 189 \\
\hline Nevada & 269415 & 243 & 891 & 1764 & 0.9 & 3.3 & 6.5 & 168 & 48777 & 108776 & 188662 & 1.8 & 4.0 & 7.0 & 277 \\
\hline & 239876 & 1016 & 2388 & 4194 & 4.2 & 10.0 & 17.5 & 91 & 14818 & 31231 & 51805 & 0.6 & 1.3 & 2.2 & 419 \\
\hline & 185030 & 398 & 1047 & 1873 & 2.2 & 5.7 & 10.1 & 120 & 170462 & 332320 & 529510 & 9.2 & 18.0 & 28.6 & 152 \\
\hline Washington & 161881 & 728 & 1709 & 3016 & 4.5 & 10.6 & 18.6 & 129 & 23579 & 47480 & 76557 & 1.5 & 2.9 & 4.7 & 282 \\
\hline (West) & 1958556 & 4492 & 13043 & 23998 & 2.3 & 6.7 & 12.3 & 168 & 588282 & 1287010 & 2173340 & 3.0 & 6.6 & 11.1 & 248 \\
\hline
\end{tabular}

$\dagger$ Soil area reported in STATSGO that excludes water, urban, bare rock, and other non-soil bodies.

$\$$ Minimum.

\$ Midpoint.

II Maximum.

\# Coefficient of variation (\%) among soil components in each state (region) with midpoint approach. 
Table 3. Soil C storage and content in the upper 2-m depth soil of Land Resources Regions (LRRs).

\begin{tabular}{|c|c|c|c|c|c|c|c|c|c|c|c|c|c|}
\hline \multirow[b]{3}{*}{ LRRs } & \multirow[b]{3}{*}{ Area $\dagger$} & \multicolumn{6}{|c|}{ Organic C } & \multicolumn{6}{|c|}{ Inorganic C } \\
\hline & & \multicolumn{3}{|c|}{ Total storage, $10^{6} \mathrm{Mg}$} & \multicolumn{3}{|c|}{ Content, $\mathrm{kg} \mathrm{m}^{-2}$} & \multicolumn{3}{|c|}{ Total storage, $10^{4} \mathrm{Mg}$} & \multicolumn{3}{|c|}{ Content, $\mathrm{kg} \mathrm{m}^{-2}$} \\
\hline & & $\operatorname{Min} \doteqdot$ & Mid§ & MaxII & Min & Mid & Max & Min & Mid & Max & Min & Mid & Max \\
\hline & $\mathbf{k m}^{2}$ & & & & & & & & & & & & \\
\hline $\mathbf{A}$ & 181215 & 1058 & 2576 & 4583 & 5.8 & 14.2 & 25.3 & 7 & 166 & 466 & 0.0 & 0.0 & $\mathbf{0 . 0}$ \\
\hline B & 259284 & 861 & 2033 & 3564 & 3.3 & 7.8 & 13.7 & 95124 & 204258 & 346910 & 3.7 & 7.9 & 13.4 \\
\hline $\mathbf{C}$ & 146884 & 530 & 1476 & 2523 & 3.6 & 10.1 & 17.2 & 2149 & 5989 & 10315 & 0.1 & 0.4 & 0.7 \\
\hline D & 1268922 & 1571 & 5644 & 10839 & 1.2 & 4.4 & 8.5 & 509899 & 1148860 & 1961895 & 4.0 & 9.1 & 15.5 \\
\hline $\mathbf{E}$ & 521994 & 1459 & 4114 & 7783 & 2.8 & 7.9 & 14.9 & 88883 & 193339 & 339461 & 1.7 & 3.7 & 6.5 \\
\hline $\mathbf{F}$ & 351842 & 1645 & 4807 & 8750 & 4.7 & 13.7 & 24.9 & 173262 & 418782 & 730236 & 4.9 & 11.9 & 20.8 \\
\hline $\mathbf{G}$ & 521442 & 1070 & 3141 & 5579 & 2.1 & 6.0 & 10.7 & 153627 & 369138 & 624753 & 2.9 & 7.1 & 12.0 \\
\hline H & 583820 & 2320 & 6440 & 11218 & 4.0 & 11.0 & 19.2 & 443497 & 967082 & 1607667 & 7.6 & 16.6 & 27.5 \\
\hline I & 169689 & 616 & 1697 & 3131 & 3.6 & 10.0 & 18.4 & 252231 & 590386 & 1027697 & 14.9 & 34.8 & 60.6 \\
\hline $\mathbf{J}$ & 139624 & 635 & 1649 & 2868 & 4.5 & 11.8 & 20.5 & 212092 & 413207 & 657484 & 15.2 & 29.6 & 47.1 \\
\hline $\mathbf{K}$ & 300269 & 3136 & 7559 & 13557 & 10.4 & 25.2 & 45.1 & 58618 & 197945 & 384521 & 2.0 & 6.6 & 12.8 \\
\hline $\mathbf{L}$ & 119997 & 1119 & 2503 & 4269 & 9.3 & 20.9 & 35.6 & 58287 & 140490 & 248896 & 4.9 & 11.7 & 20.7 \\
\hline $\mathbf{M}$ & 717615 & 6031 & 11679 & 18287 & 8.4 & 16.3 & 25.5 & 185435 & 663473 & 1240558 & 2.6 & 9.2 & 17.3 \\
\hline $\mathbf{N}$ & 603434 & 933 & 3595 & 7406 & 1.5 & 6.0 & 12.3 & 782 & 5365 & 11814 & 0.0 & 0.1 & 0.2 \\
\hline $\mathbf{O}$ & 94652 & 269 & 1029 & 2037 & 2.8 & 10.9 & 21.5 & 3418 & 19869 & 40275 & 0.4 & 2.1 & 4.3 \\
\hline $\mathbf{P}$ & 677160 & 1702 & 6173 & 11581 & 2.5 & 9.1 & 17.1 & 1509 & 4862 & 8884 & 0.0 & 0.1 & 0.1 \\
\hline $\mathbf{R}$ & 300536 & 1147 & 4185 & 8750 & 3.8 & 13.9 & 29.1 & 921 & 7656 & 17945 & 0.0 & 0.3 & 0.6 \\
\hline $\mathbf{S}$ & 99147 & 217 & 743 & 1546 & 2.2 & 7.5 & 15.6 & 0 & 65 & 213 & 0.0 & 0.0 & 0.0 \\
\hline $\mathbf{T}$ & 231303 & 2674 & 8166 & 15492 & 11.6 & 35.3 & 67.0 & 16700 & 54611 & 100832 & 0.7 & 2.4 & 4.4 \\
\hline $\mathbf{U}$ & 85410 & 1161 & 3386 & 6157 & 13.6 & 39.6 & 72.1 & 4815 & 8458 & 12914 & 0.6 & 1.0 & 1.5 \\
\hline
\end{tabular}

$\dagger$ Soil area having Land Resources Region (LRRs) information reported in STATSGO.

$\doteqdot$ Minimum.

$\S$ Midpoint.

II Maximum.

$\mathrm{m}^{-2}$. In terms of SIC, 21 to $23 \%$ of the total is in LRR D (Western Range and Irrigated Region), 17 to $20 \%$ is in LRR H (Central Great Plains Winter Wheat and Range Region), and 8 to $13 \%$ is in LRR M (Central Feed Grains and Livestock Region). The highest SIC contents (to $2.0 \mathrm{~m}$ by midpoint) are in the LRR I (Southwest Plateaus and Plains Range and Cotton Region) with $34.8 \mathrm{~kg} \mathrm{~m}^{-2}$, LRR J (Southwestern Prairies Cotton and Forage Region) with $29.6 \mathrm{~kg} \mathrm{~m}^{-2}$, and LRR H (Central Great Plains Winter Wheat and Range Region) with $16.6 \mathrm{~kg} \mathrm{~m}^{-2}$.
The spatial variability of SOC and SIC for the soil components in each LRR (three depths) is presented in Table 4. In most LRRs, as soil depth increases, the coefficient of variation of SOC in each LRR increases but that of SIC decreases. The variability of SOC and SIC varies with LRRs. The LRR C has the largest variability of SOC among the LRRs. Land resource region U, LRR T, LRR $\mathrm{K}$, and LRR L have the highest SOC contents (Table 3), as well as the highest SOC variability. In contrast, LRR I and LRR J have relatively lower SIC variability although the

Table 4. Spatial variability of soil C within each land Resource Region (LRR).

\begin{tabular}{|c|c|c|c|c|c|c|c|c|c|c|c|c|c|c|c|c|c|}
\hline \multirow[b]{3}{*}{ LRR } & \multirow{3}{*}{$\begin{array}{c}\text { Number } \\
\text { of soil } \\
\text { comp. } \dagger\end{array}$} & \multicolumn{8}{|c|}{ Organic C } & \multicolumn{8}{|c|}{ Inorganic C } \\
\hline & & \multicolumn{3}{|c|}{$0-20 \mathrm{~cm}$} & \multicolumn{3}{|c|}{$0-100 \mathrm{~cm}$} & \multicolumn{2}{|c|}{$0-200 \mathrm{~cm}$} & \multicolumn{3}{|c|}{$0-20 \mathrm{~cm}$} & \multicolumn{3}{|c|}{$0-100 \mathrm{~cm}$} & \multicolumn{2}{|c|}{$0-200 \mathrm{~cm}$} \\
\hline & & Mean $\%$ & Std§ & CVII & Mean & Std & CV & Std & $\mathbf{C V}$ & Mean & Std & CV & Mean & Std & $\mathbf{C V}$ & Std & $\mathbf{C V}$ \\
\hline $\mathbf{A}$ & 3040 & 5.51 & 5.1 & 93 & 12.64 & 11.3 & 90 & 13.9 & 98 & 0.00 & 0.0 & 3631 & 0.01 & 0.3 & 3409 & 0.3 & 3406 \\
\hline B & 5465 & 2.50 & 1.7 & 68 & 6.67 & 6.4 & 95 & 8.3 & 106 & 0.44 & 1.4 & 327 & 4.48 & 8.9 & 199 & 14.6 & 186 \\
\hline $\mathbf{C}$ & 4621 & 3.12 & 3.9 & 124 & 8.17 & 17.9 & 218 & 27.7 & 276 & 0.03 & 0.3 & 850 & 0.24 & 1.5 & 650 & 2.4 & 587 \\
\hline D & 17318 & 1.37 & 1.6 & 116 & 3.52 & 5.2 & 148 & 7.4 & 166 & 1.11 & 2.4 & 216 & 5.73 & 11.2 & 195 & 18.7 & 207 \\
\hline $\mathbf{E}$ & 9142 & 2.81 & 2.7 & 97 & 6.65 & 8.8 & 132 & 12.5 & 158 & 0.28 & 1.1 & 399 & 2.37 & 7.8 & 327 & 12.2 & 329 \\
\hline $\mathbf{F}$ & 4378 & 4.95 & 2.9 & 59 & 11.70 & 7.2 & 61 & 8.2 & 60 & 0.53 & 1.2 & 220 & 7.28 & 10.0 & 137 & 15.4 & 130 \\
\hline $\mathbf{G}$ & 6555 & 2.03 & 1.2 & 58 & 4.96 & 3.1 & 63 & 3.9 & 64 & 0.73 & 1.7 & 230 & 4.61 & 8.3 & 179 & 13.3 & 188 \\
\hline H & 6613 & 2.67 & 1.2 & 46 & 7.97 & 4.2 & 53 & 6.4 & 58 & 0.75 & 2.0 & 269 & 6.54 & 13.4 & 206 & 30.0 & 181 \\
\hline $\mathbf{I}$ & 1460 & 2.42 & 1.0 & 43 & 7.05 & 6.2 & 88 & 10.9 & 109 & 4.46 & 4.8 & 107 & 19.47 & 21.9 & 113 & 41.5 & 119 \\
\hline $\mathbf{J}$ & 1285 & 2.36 & 1.2 & 52 & 8.05 & 6.0 & 75 & 9.1 & 77 & 2.80 & 4.6 & 166 & 15.53 & 24.2 & 156 & 42.9 & 145 \\
\hline $\mathbf{K}$ & 4608 & 6.50 & 7.5 & 116 & 19.43 & 28.8 & 148 & 39.6 & 157 & 0.09 & 0.5 & 549 & 2.72 & 6.2 & 227 & 11.9 & 181 \\
\hline $\mathbf{L}$ & 1939 & 6.19 & 6.0 & 97 & 15.98 & 26.0 & 163 & 38.2 & 183 & 0.07 & 0.5 & 777 & 3.75 & 6.8 & 182 & 15.5 & 132 \\
\hline M & 9413 & 4.96 & 3.1 & 63 & 13.48 & 12.6 & 93 & 16.9 & 104 & 0.28 & 1.0 & 375 & 3.39 & 7.2 & 212 & 13.5 & 146 \\
\hline $\mathbf{N}$ & 10048 & 2.48 & 1.3 & 52 & 5.00 & 3.1 & 61 & 3.9 & 65 & 0.01 & 0.1 & 2125 & 0.04 & 0.7 & 1821 & 1.4 & 1587 \\
\hline $\mathbf{O}$ & 2038 & 3.23 & 2.1 & 64 & 8.01 & 8.1 & 101 & 13.9 & 127 & 0.05 & 0.4 & 793 & 1.10 & 2.9 & 261 & 5.8 & 278 \\
\hline $\mathbf{P}$ & 9791 & 2.20 & 1.9 & 85 & 6.09 & 9.0 & 147 & 16.2 & 178 & 0.01 & 0.1 & 2480 & 0.03 & 0.7 & 2110 & 1.2 & 1639 \\
\hline $\mathbf{R}$ & 7708 & 4.81 & 4.7 & 98 & 11.25 & 14.5 & 129 & 20.9 & 150 & 0.01 & 0.1 & 1554 & 0.08 & 0.8 & 925 & 2.2 & 858 \\
\hline $\mathbf{S}$ & 2183 & 3.04 & 2.5 & 81 & 6.19 & 12.4 & 201 & 15.2 & 202 & 0.00 & 0.0 & 5299 & 0.00 & 0.2 & 4165 & 0.3 & 4069 \\
\hline $\mathbf{T}$ & 3100 & 6.10 & 7.4 & 122 & 22.70 & 37.6 & 166 & 63.7 & 180 & 0.09 & 0.5 & 559 & 0.99 & 3.9 & 398 & 8.5 & 360 \\
\hline $\mathbf{U}$ & 542 & 7.79 & 10.7 & 137 & 28.97 & 52.6 & 181 & 66.6 & 168 & 0.32 & 2.1 & 635 & 0.87 & 5.5 & 635 & 6.0 & 605 \\
\hline Weigh & average & 3.23 & 3.3 & 103 & 8.66 & 13.5 & 156 & 19.9 & 178 & 0.56 & 1.7 & 302 & 3.82 & 9.1 & 239 & 16.7 & 228 \\
\hline
\end{tabular}
within LRR's

$\dagger$ The number of soil components having the Land Resource Region information reported in STATSGO.

$\ddagger$ Mean $\left(\mathrm{kg} \mathrm{m}^{-2}\right)$ among soil components within each LRR with midpoint approach. The means of 0-200 cm were presented as midpoint values in Table 3 . § Std: Standard deviation $\left(\mathrm{kg} \mathrm{m}^{-2}\right)$ among soil components within each LRR with midpoint approach.

II CV: Coefficient of variation (\%) among soil components within each LRR with midpoint approach. 
highest SIC contents are found here. The area-weighted coefficient of variation of SOC within each LRR at the 0to $0.2-, 0$ - to $1.0-$, and $0-$ to $2.0-\mathrm{m}$ depth increments is 103 , 156 , and $178 \%$, respectively, while the area-weighted coefficient of variation of SIC is 302,239 , and $228 \%$, respectively. The greater variability of SIC contents compared with SOC might be explained by the fact that SOC is determined by the balance of $\mathrm{C}$ inputs and losses-which is generally climatically controlled. In contrast, the SIC content is also climatically driven, but depends additionally on parent material composition, location relative to dust sources, and age, all of which add considerably to the spatial variability of SIC in soils.

One common method for calculating total SOC is to multiply the mean content of SOC by the area of a certain land use/cover or an ecosystem type. To estimate the mean SOC content, soil (pedon) data for each land use/cover or ecosystem are used (Post et al., 1982). Although the method is very useful for estimating SOC under different ecosystems and climates and for evaluating the impact of climate change on SOC pools, the accuracy of total SOC estimates obtained by this method is very variable. Based on the SOC of 111247 soil components, we found that the area-weighed coefficients of variation for SOC at the 1.0- and 2.0-m depths within each LRR of the conterminous USA are 156 and $178 \%$, respectively. This analysis is based on the assumption that the SOC in each soil component of STATSGO is homogeneous (the variance of SOC or SIC within a soil component cannot be estimated since only low and high limits of SOC or SIC are reported for each layer of component in STATSGO). The variability of SOC will be larger if variability of SOC in each soil component can be analyzed. However, no such data is presently available. As we discuss below (Table 7), these values of variance are larger than those arrived at through soil $\mathrm{C}$ tabulations made by soil taxa.

\section{Quantity and Spatial Variability of Soil Carbon in Soil Orders}

The SOC and SIC sequestered in each soil order of the USA is presented in Table 5. Due both to its large area $(27 \%$ of the soil area in the conterminous USA) and modest SOC contents, SOC in Mollisols accounts for about 31 to $39 \%$ of the total U.S. SOC stock (11 843 to $46102 \times 10^{6} \mathrm{Mg}$ ), followed by Histosols $(17-23 \%)$, Alfisols (10-12\%), and Entisols (6-11\%). Considering the SOC content to $2 \mathrm{~m}$ (midpoint approach), Histosols have the highest content $\left(140.1 \mathrm{~kg} \mathrm{~m}^{-2}\right)$, followed by Vertisols $\left(14.7 \mathrm{~kg} \mathrm{~m}^{-2}\right)$, Mollisols $\left(13.5 \mathrm{~kg} \mathrm{~m}^{-2}\right)$, and Andisols $\left(10.7 \mathrm{~kg} \mathrm{~m}^{-2}\right)$. Aridisols have the lowest SOC content with only $4.0 \mathrm{~kg} \mathrm{~m}^{-2}$.

There is zero SIC in Ultisols and very little in Andisols, which contributed essentially no SIC to the national stock. Mollisols contain 9908 to $39894 \times 10^{6} \mathrm{Mg}$ of SIC, accounting for 43 to $44 \%$ of the national total. Aridsols are second with 5630 to $22135 \times 10^{6}(24-25 \%)$, followed by Alfisols and Entisols (7-11\% and 9\%, respectively). In terms of SIC content, Vertisols have the highest mass at $23.2 \mathrm{~kg} \mathrm{~m}^{-2}$ (midpoint value), Aridisols are second with $15.9 \mathrm{~kg} \mathrm{~m}^{-2}$, and Mollisols are third $\left(11.5 \mathrm{~kg} \mathrm{~m}^{-2}\right)$.

The patterns of SOC and SIC storage vs. soil depth vary with the soil orders. Inceptisols and Alfisols have 35 and $39 \%$ (midpoint value) of their SOC in the upper $0.2 \mathrm{~m}$, while only $16 \%$ of SOC is in the upper $0.2 \mathrm{~m}$ of Histosols. Unlike SOC, most of the SIC storage is in the deeper layers. However, there are some exceptions: Andisols and Entisols have 19 and 15\% (midpoint value) of their total SIC in the upper $0.2 \mathrm{~m}$.

There is a large spatial variability of SOC and SIC in each order and at all depths (Table 6). Standard deviation (Std) describes the absolute variability of SOC and SIC within each order, and the coefficient of variation indicates the relative variability of SOC and SIC, which can be used to compare the differences in the variation of SOC and SIC among the orders, since the means of SOC (or SIC) in each order are different. Entisols and Inceptisols have the largest $\mathrm{CV}$ (or relative variability) among the orders. In terms of SIC, Andisols and Spodosols have the smallest standard deviation due to their very low SIC content. Relative variability of SIC is much larger than that of SOC within any order.

The area-weighted variability of soil $\mathrm{C}$ within the taxa of any categorical level is reported in Table 7. The standard deviation of soil C (both SOC and SIC) in taxa decreases as the taxonomic category decreases (e.g.,

Table 5. Carbon storage and content in the upper $2 \mathrm{~m}$ of the soil orders.

\begin{tabular}{|c|c|c|c|c|c|c|c|c|c|c|c|c|c|}
\hline \multirow[b]{3}{*}{ Orders } & \multirow[b]{3}{*}{ Area $\nmid$} & \multicolumn{6}{|c|}{ Organic C } & \multicolumn{6}{|c|}{ Inorganic C } \\
\hline & & \multicolumn{3}{|c|}{ Total storage, $10^{6} \mathrm{Mg}$} & \multicolumn{3}{|c|}{ Content, kg m ${ }^{-2}$} & \multicolumn{3}{|c|}{ Total storage, $10^{6} \mathrm{Mg}$} & \multicolumn{3}{|c|}{ Content, kg m ${ }^{-2}$} \\
\hline & & Min $\ddagger$ & Mid§ & MaxII & Min & Mid & Max & Min & Mid & Max & Min & Mid & Max \\
\hline & $\mathbf{k m}^{2}$ & & & & & & & & & & & & \\
\hline Alfisols & 1274102 & 2964 & 9603 & 17974 & 2.3 & 7.5 & 14.1 & 1649 & 5461 & 10296 & 1.3 & 4.3 & 8.1 \\
\hline Andisols & 68666 & 327 & 731 & 1286 & 4.8 & 10.7 & 18.7 & 1 & 2 & 3 & $\mathbf{0 . 0}$ & $\mathbf{0 . 0}$ & $\mathbf{0 . 0}$ \\
\hline Aridisols & 809423 & 942 & 3260 & 6179 & 1.2 & 4.0 & 7.6 & 5630 & 12890 & 22135 & 7.0 & 15.9 & 27.3 \\
\hline Entisols & 1054015 & 1927 & 8419 & 16645 & 1.8 & 8.0 & 15.8 & 1995 & 5112 & 8901 & 1.9 & 4.8 & 8.4 \\
\hline Histosols & 107249 & 6852 & 15022 & 26157 & 63.9 & 140.1 & 243.9 & 63 & 260 & 534 & 0.6 & 2.4 & 5.0 \\
\hline Inceptisols & 787254 & 2194 & 7011 & 13705 & 2.8 & 8.9 & 17.4 & 1956 & 4006 & 6612 & 2.5 & 5.1 & 8.4 \\
\hline Mollisols & 2020694 & 11843 & 27308 & 46102 & 5.9 & 13.5 & 22.8 & 9908 & 23181 & 39894 & 4.9 & 11.5 & 19.7 \\
\hline Spodosols & 250133 & 721 & 3071 & 6379 & 2.9 & 12.3 & 25.5 & 50 & 149 & 282 & 0.2 & 0.6 & 1.1 \\
\hline Ultisols & 860170 & 1636 & 6125 & 11927 & 1.9 & 7.1 & 13.9 & 0 & 0 & 0 & 0.0 & 0.0 & 0.0 \\
\hline Vertisols & 132433 & 712 & 1941 & 3371 & 5.4 & 14.7 & 25.5 & 1360 & 3075 & 5072 & 10.3 & 23.2 & 38.3 \\
\hline
\end{tabular}

$\dagger$ Soil area with taxonomic information reported in STATSGO.

$\uparrow$ Minimum.

$\S$ Midpoint.

II Maximum. 
Table 6. Spatial variability of soil carbon in each soil order.

\begin{tabular}{|c|c|c|c|c|c|c|c|c|c|c|c|c|c|c|c|c|c|}
\hline \multirow[b]{3}{*}{ Order } & \multirow{3}{*}{$\begin{array}{c}\text { Number } \\
\text { of soil } \\
\text { comp.I }\end{array}$} & \multicolumn{8}{|c|}{ Organic C } & \multicolumn{8}{|c|}{ Inorganic C } \\
\hline & & \multicolumn{3}{|c|}{$0-20 \mathrm{~cm}$} & \multicolumn{3}{|c|}{ 0-100 cm } & \multicolumn{2}{|c|}{$0-200 \mathrm{~cm}$} & \multicolumn{3}{|c|}{ 0-20 cm } & \multicolumn{3}{|c|}{$0-100 \mathrm{~cm}$} & \multicolumn{2}{|c|}{ 0-200 cm } \\
\hline & & Mean§ & Std $\dagger$ & $\mathrm{CV}$ † & Mean & Std & CV & Std & CV & Mean & Std & CV & Mean & Std & CV & Std & CV \\
\hline Alfisols & 18658 & 2.62 & 1.5 & 59 & 5.86 & 3.2 & 54 & 4.3 & 56 & 0.03 & 0.2 & 938 & 1.36 & 4.5 & 335 & 10.6 & 247 \\
\hline Andisols & 798 & 3.48 & 2.6 & 74 & 9.20 & 6.8 & 74 & 8.2 & 77 & 0.01 & 0.1 & 1795 & 0.02 & 0.4 & 1949 & 0.5 & 1989 \\
\hline Aridisols & 9909 & 1.19 & 0.7 & 61 & 3.07 & 1.9 & 62 & 2.8 & 68 & 1.50 & 2.7 & 178 & 9.49 & 13.1 & 138 & 23.1 & 145 \\
\hline Entisols & 16724 & 1.91 & 2.7 & 142 & 5.42 & 11.4 & 211 & 20.6 & 258 & 0.76 & 2.0 & 257 & 3.30 & 8.7 & 263 & 13.2 & 273 \\
\hline Histosols & 1692 & 22.81 & 10.1 & 44 & 97.55 & 50.3 & 52 & 75.9 & 54 & 0.01 & 0.1 & 1539 & 0.91 & 2.9 & 317 & 7.4 & 305 \\
\hline Inceptisols & 14154 & 3.45 & 4.0 & 116 & 7.39 & 8.4 & 113 & 10.8 & 121 & 0.43 & 2.1 & 489 & 3.11 & 12.1 & 388 & 19.6 & 386 \\
\hline Mollisols & 31990 & 4.31 & 2.5 & 58 & 11.26 & 8.0 & 71 & 10.3 & 76 & 0.77 & 2.2 & 290 & 5.56 & 11.5 & 207 & 22.4 & 195 \\
\hline Spodosols & 3629 & 3.70 & 2.0 & 53 & 9.86 & 5.2 & 53 & 7.6 & 62 & 0.00 & 0.0 & 5361 & 0.17 & 1.1 & 652 & 3.5 & 594 \\
\hline Ultisols & 11788 & 2.31 & 1.6 & 71 & 5.35 & 3.8 & 71 & 4.7 & 66 & 0.00 & & & 0.00 & & & & \\
\hline Vertisols & 1642 & 3.14 & 1.2 & 38 & 10.62 & 6.1 & 58 & 9.4 & 64 & 1.41 & 2.0 & 144 & 10.67 & 14.7 & 138 & 33.0 & 142 \\
\hline
\end{tabular}

II The number of soil components having the Land Resource Region information reported in STATSGO.

$\$$ Mean $\left(\mathrm{kg} \mathrm{m}^{-2}\right)$ among soil components within each LRR with midpoint approach. The means of 0-200 cm were presented as midpoint values in Table 5. $\dagger$ Std: Standard deviation $\left(\mathrm{kg} \mathrm{m}^{-2}\right)$ among soil components within each LRR with midpoint approach.

+ CV: Coefficient of variation (\%) among soil components within each LRR with midpoint approach.

order to series). The relative variability (CV) of SIC is larger than that of SOC at each depth and taxonomic category. Relative variability increases in SOC but decreases in SIC as soil depth increases for all taxonomic categories (except for soil series in SOC).

The area-weighted variability of SOC in taxa at each taxonomic categorical level of each order is presented in Fig. 3. The variability of SOC in taxa decreases as taxonomic category decreases in all soil orders, which is especially obvious moving from the family to the series categories. In Entisols and Inceptisols, variability in taxa, at any taxonomic level, is larger than that in the other soil orders.

Estimation of SOC based on Soil Taxonomy is another common approach for estimating the SOC pool of a nation or the world. Order or suborder taxa have been used to estimate the world SOC pool (Eswaran et al., 1993, 1995; Lal et al., 1998a). Likewise, taxa in the great-group category have been used to estimate the SOC pool in the conterminous USA (Kern, 1994). Results obtained in this study indicate that estimates of SOC based on taxa in the lower taxonomic levels will have higher accuracy if the sample size is fixed (Table 7). However, for large geographic areas, it is not feasible to use taxa in lower taxonomic levels since there may be too many taxa to practically evaluate. If taxa in higher taxonomic levels are used for estimating SOC, the larger the number of pedon data used, the greater the accuracy of the estimate. Due to high variability, there will be especially large inaccuracies in SIC estimations based on taxa at higher taxonomic categories. In contrast, SIC estimates made from series categories will be accurate, though subject to limitations posed by large amounts of data if applied to large spatial areas (Table 7).

The results obtained in this study (based on the analysis of 111247 soil components) suggest that predicting the SOC pool using the LRR-based method will require a larger sample size than the taxonomy-based method to arrive at similar levels of accuracy. The coefficient of variation for SOC in LRRs is 103,156 , and $178 \%$ for the 0.2-, 1-, and 2-m depths, respectively (Table 4). In contrast, the coefficient of variation for SOC in the orders is 82,107 , and $125 \%$ for the same depths (Table 7 ), a modest improvement over the LRR approach. The

Table 7. Area-weighted variability of soil $\mathrm{C}$ in the taxa of each taxonomic category by depth.

\begin{tabular}{|c|c|c|c|c|c|c|c|c|}
\hline \multirow[b]{2}{*}{ Depth } & \multicolumn{2}{|c|}{ Taxonomy } & \multicolumn{3}{|c|}{ Organic C } & \multicolumn{3}{|c|}{ Inorganic C } \\
\hline & Category & Number of taxa & Std $\dagger$ & Mean $\div$ & CV§ & Std & Mean & $\mathbf{C V}$ \\
\hline cm & & & $\%$ & $\mathbf{k g ~ ~ m ^ { - 2 }}$ & & $\mathbf{k g ~ ~ m ^ { - 2 }}$ & $\%$ & \\
\hline \multirow[t]{6}{*}{ 0-20 } & Order & 10 & 2.64 & 3.22 & 82 & 1.80 & 0.56 & 322 \\
\hline & Suborder & 48 & 2.32 & 3.22 & 72 & 1.71 & 0.56 & 305 \\
\hline & Great group & 206 & 2.04 & 3.22 & 63 & 1.44 & 0.56 & 257 \\
\hline & Subgroup & 1057 & 1.71 & 3.21 & 53 & 1.28 & 0.56 & 227 \\
\hline & Family & 5959 & 1.20 & 3.21 & 37 & 0.59 & 0.56 & 105 \\
\hline & Series & 12788 & 0.61 & 3.21 & 19 & 0.38 & 0.56 & 67 \\
\hline \multirow[t]{6}{*}{ 0-100 } & Order & 10 & 9.30 & 8.66 & 107 & 9.43 & 3.82 & 247 \\
\hline & Suborder & 48 & 8.55 & 8.66 & 99 & 9.04 & 3.82 & 237 \\
\hline & Great group & 206 & 7.41 & 8.64 & 86 & 7.89 & 3.82 & 207 \\
\hline & Subgroup & 1057 & 6.25 & 8.59 & 73 & 6.64 & 3.83 & 173 \\
\hline & Family & 5959 & 3.97 & 8.59 & 46 & 3.33 & 3.83 & 87 \\
\hline & Series & 12788 & 1.46 & 8.59 & 17 & 1.70 & 3.83 & 44 \\
\hline \multirow[t]{6}{*}{ 0-200 } & Order & 10 & 14.02 & 11.20 & 125 & 17.40 & 7.35 & 237 \\
\hline & Suborder & 48 & 13.12 & 11.20 & 117 & 16.70 & 7.35 & 227 \\
\hline & Great group & 206 & 11.10 & 11.16 & 99 & 14.91 & 7.35 & 203 \\
\hline & Subgroup & 1057 & 9.17 & 11.08 & 83 & 12.65 & 7.38 & 171 \\
\hline & Family & 5959 & 5.60 & 11.08 & 51 & 6.62 & 7.38 & 90 \\
\hline & Series & 12788 & 2.26 & 11.08 & 20 & 2.91 & 7.38 & 39 \\
\hline
\end{tabular}

$\dagger$ Std: Area-weighted standard deviation $\left(\mathrm{kg} \mathrm{m}^{-2}\right)$ among soil components in each taxa with midpoint approach. Mean: Mean content of soil components with midpoint approach.

§ CV: Area-weighted coefficient of variation (\%) among soil components in each taxa with midpoint approach. 

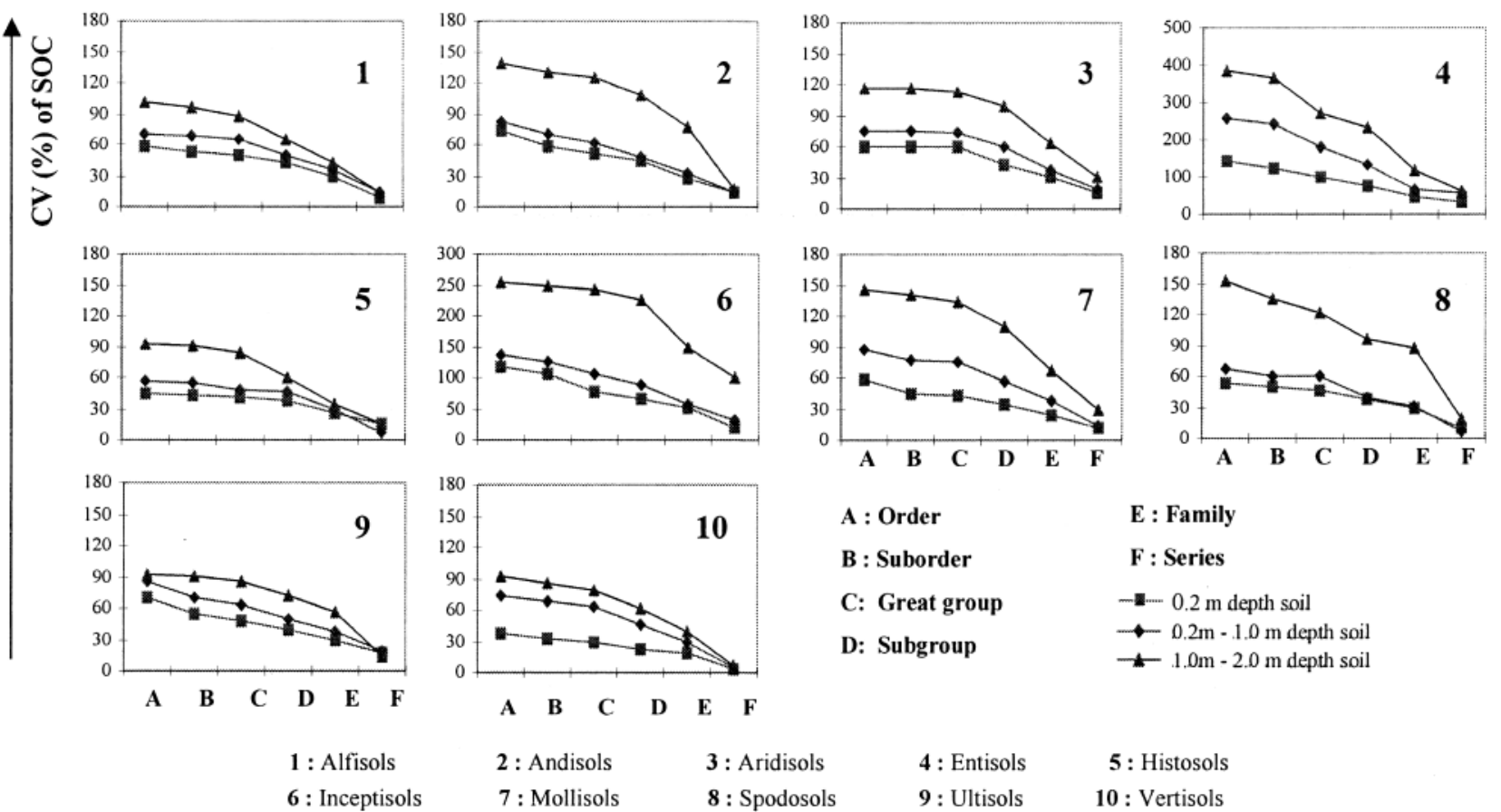

Fig. 3. Coefficient of variation (CV) of soil organic carbon (SOC) among soil components in taxa of each taxonomic category of each soil order, by soil depth (midpoint method).

coefficient of variation for SOC substantially decreases when estimates are based on soil order approach. This is undoubtedly due to the fact that taxonomic designations are successful at grouping soils of similar characteristics, whereas resource regions may indeed have one dominant state factor, while many others (which may have affects on soil $\mathrm{C}$ pools) vary considerably. Therefore, a higher accuracy estimate of SOC can be expected when taxa of lower taxonomic categories are used to estimate the SOC pool over a geographical area.

\section{CONCLUSIONS}

In this paper, the range of SOC and SIC in the USA was estimated using the STATSGO. Our analysis of SOC compliments previous studies using STATSGO by including the low and high limits in soil $\mathrm{C}$ estimates, the evaluation of $\mathrm{C}$ to greater soil depths, and by examining the variability in the data. Our analysis of SIC at a national scale was an exercise to contribute to the soil carbon inventory literature based on the STATSGO data.

To estimate soil $\mathrm{C}$ for a large area, we have observed that LRR (land cover or ecosystems)-based methods will need a larger sample size than the taxonomy-based method to achieve the same level of accuracy since the variation of SOC in a LRR population is larger than that in the Soil Taxonomy population. Variation within soil taxa becomes smaller as taxonomic category becomes more detailed, especially from the family to the series categories. Due to high variability, there will be especially large inaccuracies in SIC estimations based on taxa at higher taxonomic categories. An unanticipated finding was that a substantial SIC pool exists in the central USA between depths of 1 to $2 \mathrm{~m}$.
When SIC in the 2.0-m soil is considered, a large SIC pool was found in the Midwest where the mean annual precipitation (MAP) is about 700 to $1000 \mathrm{~mm}$. While the SIC in the upper $1.0 \mathrm{~m}$ is generally leached out in these climates, the deeper depth increment still retains some combination of primary and secondary carbonates.

We conclude by noting that the patterns of SOC and SIC across the landscape are determined by the widely varying combinations of vegetation, climate (precipitation and temperature), topography, soil parent materials, and landform age (Jenny, 1994) that occur across the country. In this paper we have first focused only on soil C storage and its partitioning among LRRs and soil orders, with little discussion as to why the trends are present. In a companion paper, we examine the factors controlling soil $\mathrm{C}$ distribution and discuss the implications with respect to global change and land use activities.

\section{ACKNOWLEDGMENTS}

We thank Kit Paris, Eric Vinson, Sharon Waltman, and Norman B. Bliss for detailed explanations of the STATSGO database; Doug Miller and Sharon Waltman for providing the MLRA coverage; Ruiling Pu and Ming Xu for commenting on an earlier draft of this paper. Drs. J. Galbraith and B. Amichev provided helpful assistance and comments on an earlier version of the paper. This research was partially supported by the Kearney Foundation of Soil Science.

\section{REFERENCES}

Amichev, B.Y., and J.M. Galbraith. 2004. A revised methodology for estimation of forest soil carbon from spatial soils and forest inventory data sets. Environ. Manage. 33:74-86.

Bliss, N.B., S.W. Waltman, and G.W. Peterson. 1995. Preparing a soil 
carbon inventory for the United States using geographical information systems. p. 275-295. In R. Lal et al. (ed.) Soils and global change. Adv. Soil Sci. CRC/Lewis Publishers, Boca Raton, FL.

Brejda, J.J., M.J. Mausbach, J.J. Goebel, D.L. Allan, T.H. Dao, D.L. Karlen, T.B. Moorman, and J.L. Smith. 2001. Estimating surface soil organic carbon content at a regional scale using the National Resource Inventory. Soil Sci. Soc. Am. J. 65:842-849.

Davidson, E.A., and P.A. Lefebvre. 1993. Estimating regional carbon stocks and spatially covarying edaphic factors using soil maps at three scales. Biogeochemistry 22:107-131.

Davidson, E.A. 1995. Spatial covariation of soil organic carbon, clay content, and drainage class at a regional scale. Landscape Ecol. 10:349-362.

Environmental Systems Research Institute. 1999. Arcview GIS 3.2 software. http://www.esri.com/software/arcview/ (verified 23 Aug. 2005). ESRI, Redlands, CA.

Environmental Systems Research Institute. 1998. Arc/info 7.2.1 (unix) software. http://www.esri.com/software/arcgis/arcinfo/ (verified 23 Aug. 2005). ESRI, Redlands, CA.

Eswaran, H., E.V.D. Berg, and P. Reich. 1993. Organic carbon in soils of the world. Soil Sci. Soc. Am. J. 57:192-194.

Eswaran, H., E.V.D. Berg, P. Reich, and J. Kimble. 1995. Global carbon resources. p. 27-43. In Lal R. et al. (ed.) Soils and global change. CRC/Lewis Publishers, Boca Raton, FL.

Franzmeier, D.P., G.D. Lemme, and R.J. Miles. 1985. Organic carbon in soils of north central United States. Soil Sci. Soc. Am. J. 49: 702-708.

Galbraith, J.M., P.J.A. Kleinman, and R.B. Bryant. 2003. Sources of uncertainty affecting soil organic carbon estimates in Northern New York. Soil Sci. Soc. Am. J. 67:1206-1212.

Gnedenko, B.V., and A.Y. Khinchin. 1962. An elementary introduction to the theory of probability. Dover Publ., Inc. New York.

Grossman, R.B., R.J. Ahrens, L.H. Gile, C.E. Montoya, and O.A. Chadwick. 1995. Areal evaluation of carbonate carbon in a desert area of southern New Mexico. p. 81-91. In R. Lal et al. (ed.) Soils and global change. CRC/Lewis Publisher, Boca, FL.

Homann, P.S., P. Sollins, M. Giorella, T. Thorson, and J.S. Kern. 1998. Regional soil organic carbon estimates for Western Oregon by multiple approaches. Soil Sci. Soc. Am. J. 62:789-796.

Huntington, T.G., D.F. Ryan, and S.P. Hamburg. 1988. Estimating soil nitrogen and carbon pools in a northern hardwood forest ecosystem. Soil Sci. Soc. Am. J. 52:1162-1167.

Jenny, H. 1994. Factors of soil formation: A system of quantitative pedology. Dover Publ., Inc. New York.

Jenny, H., and C.D. Leonard. 1934. Functional relationships between soil properties and rainfall. Soil Sci. 38:363-381.

Kern, J.S. 1994. Spatial patterns of soil organic carbon in the contiguous United States. Soil Sci. Soc. Am. J. 58:439-455.
Lacelle, B., S. Waltman, N. Bliss, and F. Orozco-chavez. 2001. Methods used to create the North American soil organic carbon digital database. p. 485-494. In R. Lal et al. (ed.) Assessment methods for soil carbon. Adv. Soil Sci. CRC/Lewis Publisher, Boca Raton, FL.

Lal, R., J.M. Kimble, and R.F. Follett. 1998a. Land use and soil C pools in terrestrial ecosystems. p. 1-10. In R. Lal et al. (ed.) management of carbon sequestration in soil. CRC/Lewis Publisher, Boca Raton, FL.

Lal, R., J.M. Kimble, and R.F. Follett. 1998b. Pedospheric processes and the carbon cycle. p. 1-8. In R. Lal et al. (ed.) Soil processes and the carbon cycle. CRC/Lewis Publisher, Boca Raton, FL.

Microsoft Corporation. 2000. Microsoft Access software. http://www. microsoft.com/office/access/ (verified 23 Aug. 2005). Microsoft Inc. Redmond, WA.

Monger, H.C., and J.J. Matrinez-Rios. 2000. Inorganic carbon sequestration in grazing lands. p. 87-118. In R.F. Follett et al. (ed.) The potential of U.S. grazing lands to sequester carbon and mitigate the greenhouse effect. CRC/Lewis Publisher, Boca Raton, FL.

Post, W.M., W.R. Emanuel, P.J. Zinke, and A.G. Stangenberger. 1982. Soil carbon pools and world life zones. Nature (London) 298: 156-159.

Reybold, W.U., and W.T. Gale. 1989. Soil geographic data bases. J. Soil Water Conserv. 44:28-30.

Schlesinger, W.H. 1982. Carbon storage in caliche of arid soils: A case study from Arizona. Soil Sci. 133:247-255.

Schlesinger. W.H. 1997. Biogeochemistry: An analysis of global change 2nd ed. Academic Press. New York.

Schruben, P.S., E.A. Raymond, and W.J. Bawiec. 1998. Geology of the conterminous United States at 1:2,500,000 scale-A digital representation of the 1974 P.B. King and H.M. Beikman map. U.S. Geographic Survey Digital Data Series DDS-11 release 2. U.S. Geological Survey, Reston, VA.

SCS. 1992. State soil geographic data base (STATSGO) data user guide. USDA-SCS. National Soil Survey Center, Lincoln, NE.

Sims, Z.R., and G.A. Neilsen. 1986. Organic carbon in Montana soils as related to clay content and climate. Soil Sci. Soc. Am. J. 50: 1269-1271.

Soil Survey Staff. 1999. Soil taxonomy: A basic system of soil classification for making and interpreting soil surveys. Second ed. USDA. SCS Agricultural Handbook no. 436. U.S. Gov. Print. Office, Washington, DC.USDA-SCS. 1981. Land resource regions and major land resource areas of the United States. USDA-NRCS Agric. Handb. 296. Rev. 1984. U.S. GOV. Print. Office, Washington, DC. Available also online at http://www.nrcs.usda.gov/technical/land/ meta/m3962.html (verified 25 Aug. 2005).

USDA-NRCS. 2003. National soil survey handbook. Title 430-VI. Available online at http://soils.usda.gov/technical/handbook/ (verified 25 Aug. 2005). 